Is there a public interest in knowing what is going on in society? : A comparative study of the European Courts

\title{
Dahlberg, Maija
}

2019-10-01

Dahlberg , M \& Wyatt , D 2019 , ' Is there a public interest in knowing what is going on in society? A comparative study of the European Courts ' , Maastricht Journal of European and Comparative Law , vol. 26 , no. 5 , pp. 691-712 . https://doi.org/10.1177/1023263X19865839

http://hdl.handle.net/10138/311121

https://doi.org/10.1177/1023263X19865839

unspecified

acceptedVersion

Downloaded from Helda, University of Helsinki institutional repository.

This is an electronic reprint of the original article.

This reprint may differ from the original in pagination and typographic detail.

Please cite the original version. 
Is there a public interest in knowing what is going on in society? A comparative study of the European Courts

Maija Dahlberg* and Daniel Wyatt**

\begin{abstract}
Both of the European courts, namely the European Court of Human Rights and the Court of Justice of the European Union, have well-established case law on the public's right of access to official documents. The core of the right is the same in both of the courts' jurisdictions but the interpretations concerning the breadth of the right are very different. One fundamental reason for the public's right of access to information being understood differently by each of these courts is their divergent approaches to the assessment of the public interest associated with an individual's request for information. While the ECtHR openly evaluates the public interest or interests involved in the disclosure of an official document, the CJEU gives this factor little or no weight. In this article, our main argument is that CJEU should follow the ECtHR's interpretation of the public interest in order to give the right of access to documents the same scope in both legal regimes and, in doing so, fulfil the requirements stemming from Article 52(3) of the Charter of Fundamental Rights of the European Union.
\end{abstract}

\title{
Keywords
}

Access to documents, transparency, the European Court of Human Rights, the Court of Justice of the European Union, public interest

\section{Introduction}

It is trite these days to say that transparency is a desirable, if not necessary, part of modern democratic governance. Almost all of the many moving parts of government should, according to the generally accepted logic of openness, be subject to its reach. ${ }^{1}$ This seemingly accepted fact appears to be now so orthodox that it occupies a central place in the two significant European legal orders: the European Union (EU) and that built upon the European Convention on Human Rights (ECHR) as adjudicated by the European Court of Human Rights (ECtHR). For example, within the EU, the European Court of Justice (ECJ) in the case Turco emphasised the democratic importance of the concept, noting that the increased openness of the EU institutions is fundamental as it secures their legitimacy, effectiveness, the accountability of their actors as well as enables the participation of citizens in decision-making processes. ${ }^{2}$ The ECtHR, on the other hand, has expressed that a person's right of access to government-held information, broadly understood, is a 'genuine pillar of democratic governance'. ${ }^{3}$ The public's right to know what is going on in our governments is therefore not a marginal question and the ability of the public to access information should be effectively protected.

\footnotetext{
${ }^{1}$ C. Grønbech-Jensen, 'The Scandinavian tradition of open government and the European Union: Problems of compatibility?', 5 Journal of European Public Policy (1998), p. 187.

${ }^{2}$ Joined Cases C-39/05 P and C-52/05 P Sweden and Maurizio Turco v. Council, EU:C:2008:374, para. 45.

${ }^{3}$ ECtHR, Magyar Helsinki Bizottság v. Hungary, Judgment of 8 November 2016, Application No. 18030/11, GC, para. 161.
} 
To this end, the active right of an individual to access information can be found in both of the relevant European legal systems, however in somewhat different forms. In the EU regime, the right of access to documents is protected explicitly and broadly in primary law ${ }^{4}$ and in detail in secondary law, namely the Access to Institutional Documents Regulation 1049/2001 (Regulation 1049/2001). ${ }^{5}$ Whereas in the ECHR system, the right of access to documents is derived from the freedom of expression and information found in Article 10 ECHR. ${ }^{6}$ Further, the ECHR system recognises the right of access to information, whereas in the EU system the right of access to documents is protected. We argue, however, that the distinction is not crucial. Namely, it seems that the ECtHR uses right of access to information as a synonym for the right of access to documents. ${ }^{7}$ Consequently, this article uses both the right of access to documents and access to information interchangeably.

Deeply intertwined with the general notion of transparency, and the more specific one of access to information or documents, is that of the public interest. Public interest argumentation is directly connected with the right of the public to take part in public affairs and, consequently, with questions of democracy and the accountability of public authorities. It is in essence the public interest underpinning any request for information that draws a line between the situation at hand to even bigger questions regarding the openness of public authorities. ${ }^{8}$ In other words, information can often be understood to be released in a specific case because it is in the public interest that the information be disclosed: even if that public interest is as simple as the general pursuit of government openness or, perhaps, concerns about violations of human rights or environmental laws. Both of the relevant systems of document access visibly highlight this concept of the public interest.

With respect to the ECtHR, the evaluation of the public interest is fundamental to the very idea of access to information because it determines the breadth of the right of access to documents in the case at hand. Further, the public interest behind the information request also affects the ECtHR's interpretation of whether the right of access to documents overrides any other competing interests. The evaluation of the public interest is undertaken concretely by the ECtHR and is an essential element in deciding whether the authorities' choice to not disclose requested information was 'necessary in a democratic society'. In addition to the evaluation of the public interest behind the information request, the ECtHR places weight upon the extent of the rejection and the reasons given by the non-disclosing authorities. In other words, the

\footnotetext{
${ }^{4}$ Article 15(3) TFEU and Article 42 Charter of Fundamental Rights of the European Union.

${ }^{5}$ Regulation (EC) 1049/2001 regarding public access to European Parliament, Council and Commission Documents, O.J. 2001, L 145/43.

${ }^{6}$ Convention for the Protection of Human Rights and Fundamental Freedoms, CETS No. 005, came into force on 3 September 1953.

${ }^{7}$ See e.g. in Leander (ECtHR, Leander v. Sweden, Judgment of 26 March 1987, Application No. 9248/81, para. 74) the ECtHR uses term 'a right of access to register containing information'; in ECtHR, Loiseau v. France, Decision of 18 November 2003, Application No. 46809/99, extracts, the ECtHR uses term 'a right of access to administrative data and documents'; also 'access to the archives' (in ECtHR, Grupo Interpres SA v. Spain, Decision of 7 April 1997, Application No. 32849/96, p. 150) has been used by the ECtHR. Further, the Council of Europe Convention is named 'Access to Official Documents'. Moreover, researchers have also used access to (official/public) documents as a synonym for access to information, see D. Voorhoof, 'Freedom of journalistic news-gathering, access to information and protection of whistleblowers under Article 10 ECHR and the standards of the Council of Europe' in O. Andreotti et al (eds.), Journalism at risk: Threats, Challenges and Perspectives (Council of Europe Publishing, 2015), p. 119 ('access to public documents'); W. Hins and D. Voorhoof, 'Access to State-Held Information as a Fundamental Right under the European Convention on Human Rights' EuConst (2007), p. 114 ('access to official documents').

${ }^{8}$ See e.g. A. Florini, 'Introduction: The Battle Over Transparency' in A. Florini (ed.), The Right to Know: Transparency for an Open World (Columbia University Press, 2007), p. 3.
} 
national authorities must show that they have taken the public interest in disclosure seriously and subsequently balanced it against the competing interests.

The EU access to documents system set up by Regulation 1049/2001, on the other hand, works somewhat differently, at least on its face. Based on a general 'presumption of openness' of EU documents, ${ }^{9}$ the Regulation contains a series of discrete exceptions to disclosure as the only bases upon which the institutions can keep documents secret. However, a document may still be released even if nominally protected by an exception to disclosure if an 'overriding public interest in disclosure' (OPID) exists in the circumstances. The public interest, therefore, at least ostensibly tempers the ability of the institutions to keep documents secret. In both systems then, this notion of the public interest essentially determines the scope of an individual's right of access to documents. With all of this information in mind, the aim of this article is to examine and compare how the two European courts, that is the ECtHR and the Court of Justice of the European Union (CJEU), take this notion of the public interest into account when determining cases concerning the right of access to information.

The reason for seeking to undertake this task stems from the nature of the relationship between the ECHR and the Charter of Fundamental Rights of the European Union (the Charter). According to Article 52(3) of the Charter, 'In so far as the Charter contains rights which correspond to rights guaranteed by the Convention for the Protection of Human Rights and Fundamental Freedoms, the meaning and scope of those rights shall be the same as those laid down by the said Convention.' Consequently, the Charter connects the interpretations of fundamental rights, such as the right of access to information, and essentially demands that the CJEU should follow the line of interpretation enunciated by the ECtHR. ${ }^{10}$

The clear purpose of Article 52(3) is to avoid conflicts between the two European courts as regards the existence and nature of similar rights. Further, the provision could even be read as containing an obligation for the CJEU to respect the ECtHR case law. ${ }^{11}$ However, many examples can be identified in the CJEU's human rights cases where the ECHR has not been considered at all. ${ }^{12}$ The difficult question relating to Article 52(3) of the Charter is,

\footnotetext{
${ }^{9}$ D. Curtin and P. Leino, 'In Search of Transparency for EU Law-Making: Trilogues on the Cusp of Dawn', 54 CMLR (2017), p. 1707.

${ }^{10}$ On the impacts of the Article 52(3) Charter, see e.g. K. Lenaerts and E. de Smijter, 'The Charter and the Role of the European Courts' 8 MJECL (2001), p. 99; N.-L. Arold Lorenz et al, The European Human Rights Culture - A Paradox of Human Rights Protection in Europe? (Martinus Nijhoff, 2013), p. 200; P. Lemmens, 'The Relation between the Charter of Fundamental Rights of the European Union and the European Convention on Human Rights - Substantive Aspects', 8 MJECL (2001), p. 49-67.

${ }^{11}$ N.-L. Arold Lorenz et al, The European Human Rights Culture, p. 200; for cases where the CJEU has interpreted the Charter provisions corresponding to the ECHR, see e.g. Case C-353/16 MP v Secretary of State for the Home Department, ECLI:EU:C:2018:276, paras. 37-43; Case C-175/17 $X v$ Belastingdienst/Toeslagen, ECLI:EU:C:2018:776, para. 35; Case C-180/17 X and $Y$ v. Staatssecretaris van Veiligheid en Justitie, EU:C:2018:775, para. 31; Case C-673/16 Relu Adrian Coman and Others v. Inspectoratul General pentru Imigrări and Ministerul Afacerilor Interne, EU:C:2018:385, para. 49-50. See also an argument that the ECHR as interpreted by the ECtHR is the prime source for EU fundamental rights, determining their material scope and interpretation (V. Abazi and C. Eckes, 'Closed evidence in EU courts: security, secret and access to justice' 55 CMLR (2018), p. 765).

${ }^{12}$ B. de Witte, 'The Use of the ECHR and Convention Case Law by the European Court of Justice', in P. Popelier, C. Van de Heyning and P. Van Nuffel (eds.), Human Rights Protection in European Legal Order: The interaction between the European and the national courts (Intersentia, 2011), p. 25; on CJEU's human rights cases where the ECHR is ignored, see e.g. Case C-486/14 Criminal proceedings against Piotr Kossowski, ECLI:EU:C:2016:483; Case C-526/14 Tadej Kotnik and Others v Državni zbor Republike Slovenije, ECLI:EU:C:2016:570; Case C-133/15 H.C. Chavez-Vilchez and Others v Raad van bestuur van de Sociale verzekeringsbank and Others, ECLI:EU:C:2017:354; Case C-362/14 Maximillian Schrems v
} 
however, what is actually meant by 'corresponding rights'? From the outset, the text of the Charter does not correspond exactly to the text of the ECHR: the wording and structure of the corresponding Charter provisions are very different from their ECHR counterparts. In the nonbinding Explanations related to the Charter, there is a list concerning rights of Charter 'which may at the present stage (...) be regarded as corresponding to rights in the ECHR'. ${ }^{13}$ However, some caution is required given that the explanations are based on a relatively narrow understanding of what are rights 'corresponding' to rights already guaranteed by the ECHR. ${ }^{14}$ Consequently, the precise meaning of Article 52(3) remains disputed due to the vague manner in which the corresponding rights are identified and the ongoing debate about the authoritative status of Strasbourg case law. ${ }^{15}$

Differences between, and special features of, the regulatory environments concerning the right of access to documents, court proceedings in general and legal cultures and legal systems as a whole must be taken into account when comparing the case law of these two European courts. ${ }^{16}$ This article, however, concentrates on the concrete question of access to documents which is, in essence, the same in both systems. The crux of this part of the argument is that even though there is no explicit corresponding right of access to documents in the text of the ECHR, this fact is not decisive since, as has also been argued by other commentators, the focus should be upon whether the corresponding right is, in practice, protected in the ECHR system through the case law of the ECtHR. ${ }^{17}$ In addition, it stems also from the legal explanations related to the Charter that the meaning and scope of guaranteed rights are determined not only by the text of those instruments, but also by the case law of the ECtHR and by the CJEU. ${ }^{18}$ Consequently, we emphasise that the interpretation of 'corresponding' rights of Article 52(3) of the Charter should be broad and take into account whether the corresponding right actually exists in the ECHR system rather than focus solely on the formal or semantic question of whether the precise corresponding right can be found in the text of the ECHR and the Charter. ${ }^{19}$ Accordingly, we consider that the right of access to documents provided by Article 42

\footnotetext{
Data Protection Commissioner, ECLI:EU:C:2015:650; Case C-83/14 "CHEZ Razpredelenie Bulgaria" AD v Komisia za zashtita ot diskriminatsia, ECLI:EU:C:2015:480.

${ }^{13}$ Explanation on Article 52 of the Explanations relating to the Charter of Fundamental Rights, [2007] OJ C303/17 [emphasis added].

${ }^{14}$ P. Lemmens, 8 MJECL (2001), p. 55.

${ }^{15}$ L. Halleskov Storgaard, 'Composing Europe's Fundamental Rights Area: A Case for Discursive Pluralism' 17 Cambridge Yearbook of European Legal Studies (2015), p. 221 and sources listed. On questioning the authoritative status of the ECHR in the EU legal order, see e.g. Case C-426/16 Liga van Moskeeën en Islamitische Organisaties Provincie Antwerpen, VZW and Others v. Vlaams Gewest, EU:C:2018:335, para. 40; Case C-617/10 Åklagaren v Hans Åkerberg Fransson, ECLI:EU:C:2013:105, para. 44; Case C-398/13 P Inuit Tapirit Kanatami and Others $v$ European Commission, ECLI:EU:C:2015:535, para. 45.

${ }^{16}$ With respect to the comparison of different legal cultures and legal systems, see e.g. M. Siems. Comparative Law (2nd edition, Cambridge University Press, 2018), p. 17-19.

${ }^{17}$ There are some Charter rights which are not expressly stated by the ECHR, for example, rights with respect to the protection of personal data (Article 8 Charter). It is clear, however, that these rights (such as the rights under Article 8 Charter that are in practice protected in the case law regarding Article 8 ECHR relating to private life) when appearing in the case law of the ECtHR must be seen as 'corresponding rights' under Article 52(3) Charter, see N.-L. Arold Lorenz et al, The European Human Rights Culture, p. 162; P. Lemmens, 8 MJECL (2001), p. 5567.

${ }^{18}$ On support for the argument to take the case law of the ECtHR into account when interpreting Article 52(3) of the Charter, see e.g. K. Lenaerts and E. de Smijter, 8 MJECL (2001), p. 99; N.-L. Arold Lorenz et al., The European Human Rights Culture, p. 204.

19 Such an interpretation of the relationship between the ECHR and the Charter on the topic of access to information appears to have been put forward by Advocate General Kokott in Case C-139/07 P, Commission v Technische Glaswerke Ilmenau, EU:C:2009:520, para. 47 and fn 18.
} 


\section{Charter corresponds to the right of access to information provided by Article $10 \mathrm{ECHR}$ within the meaning of Article 52(3) Charter.}

Interestingly, both of the relevant European courts have largely developed their access to information jurisprudence independently: the ECtHR only recently referred to EU access to documents legislation, ${ }^{20}$ and, in the EU, the CJEU either does not refer to ECtHR jurisprudence or, in the few times that it has mentioned the court with respect to access to documents issues, perfunctorily dismisses it. Taking into account that they both struggle with more or less similar questions related to the right of access to documents, particularly vis-à-vis the determination of issues relating to the public interest, it is surprising that they do not look to see how the other has solved particular problems (or at least they do not reveal that they have done so). Further, considering that Article 52(3) of the Charter requires the CJEU to essentially follow the line of interpretation enunciated by the ECtHR, it is surprising that the case law praxis by the ECtHR has not been engaged with in any substantive manner by the CJEU, even when it has been brought to its attention. ${ }^{21}$ Fascinatingly, no significant research has been undertaken regarding the relationship between the ECtHR's jurisprudence and the CJEU's jurisprudence on access to documents ${ }^{22}$; this article aims to fill some of the gap that exists in the literature. In light of the above, we seek essentially to argue that the way in which the CJEU currently interprets the notion of the OPID is oppressively restrictive and, therefore, does not correspond with the ECtHR's understanding of the public interest in access to information matters. For this reason, the CJEU should, according to its responsibilities under Article 52(3) of the Charter, take the ECtHR jurisprudence on the public interest in access to documents cases seriously, or, at the very least, more seriously.

The structure of the contribution is as follows. First, the right of access to information in the context of the ECHR will be looked at. The focus here is on the public interest argumentation used by the ECtHR in its cases concerning the right of access to information. Next, the substance of the right of access to documents in the EU legal system will be introduced and the concept of the OPID as interpreted by the CJEU will be explored and then compared against the ECtHR public interest argumentation previously outlined. Following this, the key part of the article analyses further factors and problems relating to the unsatisfactory state of public interest argumentation by the CJEU in access to documents matters. The essential question to be answered then is: how and to what extent can and/or should the public interest argumentation developed by the ECtHR be utilised in the access to documents cases before the CJEU. Finally, conclusions will be drawn.

\section{The right of access to information in the Council of Europe's legal system}

\section{A. The development of the right of access to information under Article 10 ECHR}

Although the ECHR does not contain an express right of access to documents held by public authorities, its existence can nevertheless be regarded as existing within the scope of Article

\footnotetext{
${ }^{20}$ ECtHR, Magyar Helsinki Bizottság v. Hungary, para. 144.

21 See D. Adamski, 'Approximating a workable compromise on access to official documents: The 2011 Developments in the European courts' 49 CMLR (2012), p. 547; see e.g. Case C-28/08 P Commission v. Bavarian Lager, EU:C:2010:378 and Case T-115/13 Dennekamp v. Parliament, EU:T:2015:497.

${ }^{22}$ See e.g. B. Driessen, Transparency in EU Institutional Law, A Practitioner's Handbook (2nd, revised edition, Kluwer Law International, 2012) p. 268-269, where the possible influence of the ECtHR's case law upon the CJEU's cases on access to documents is described only as 'an interesting development worth mentioning'.
} 
10 ECHR (freedom of expression and information). ${ }^{23}$ The ECtHR has abandoned its original position that the ECHR should be interpreted from a literal point of view. ${ }^{24}$ Instead, the ECHR should be considered as a living instrument which should be interpreted dynamically and taking into account present day conditions. ${ }^{25}$ The gradual recognition of the right of access to stateheld information under Article 10 ECHR is a perfect example of the unique interpretation methods of the ECtHR: even if the text of the Article 10 ECHR has remained unchanged, the right has been gradually recognised. ${ }^{26}$ Consequently, the right of access to public documents is a new development in the ECHR system which expands the scope of application of Article 10 ECHR further and has instigated a discussion regarding certain positive obligations to provide access to information. ${ }^{27}$

The evolution of the recognition of the right of access to information under Article 10 ECHR can be divided into different phases. ${ }^{28}$ For a long time, the ECtHR was reluctant to recognise that the article could be interpreted as granting individuals a right to access state-held information. ${ }^{29}$ The logic was that Article 10 ECHR protects everyone's freedom to receive information but there is no general right of access to information. ${ }^{30}$

Significantly, however, several years later the ECtHR recognised the applicability of Article 10 ECHR in cases where public authorities had refused to provide information of public interest. ${ }^{31}$ Later on, the ECtHR implicitly recognised a right of access to information under Article $10 .{ }^{32}$ The ECtHR eventually came to recognise, in some form, a right of access to

\footnotetext{
${ }^{23}$ Article 10(1) ECHR provides in its relevant part: 'Everyone has the right of freedom of expression. This right shall include freedom to hold opinions and to receive and impart information and ideas without interference by public authority and regardless of frontiers...'. However, within the Council of Europe the Convention of Access to Official Documents (CETS No.205) has been accepted in 2009 and is waiting to come into force (nine out of a required ten ratifications have occured by 11 March 2019). Remarkably, the Convention on Access to Official Documents is the first and only internationally binding treaty to recognise a general right of access to information. The ECtHR has used the yet non-binding treaty as indicative of 'a definite trend towards European standard' when strengthening the right of access to information under Article 10 ECHR (ECtHR, Magyar Helsinki Bizottság v. Hungary, para. 145).

${ }^{24}$ On the interpretation methods of the ECtHR, see e.g. D.J. Harris et al, Harris, O'Boyle \& Warbrick: Law of the European Convention on Human Rights (3rd edition, Oxford University Press, 2014), p. 7-24.

${ }^{25}$ On the criticism of the living instrument doctrine and the expansion of Convention rights, see e.g. R. Spano, 'The European Court of Human Rights and National Courts: A Constructive Conversation or a Dialogue of Disrespect?' 33 NJHR (2015), p. 7-9; G. van der Schyff, 'Two-stage Rights in the ECHR' in E. Brems and J. Gerards (eds.), Shaping Rights in the ECHR, The Role of the European Court of Human Rights in Determining the Scope of Human Rights (Cambridge University Press, 2013), p. 79-81.

${ }^{26}$ Taking into account the importance of freedom of expression and information in a democratic society it is held surprising that the ECtHR has been reluctant to guarantee a general right to obtain information from authorities, see P. Tiilikka, 'Access to Information as Human Right in the Case Law of the European Court of Human Rights' 5 Journal of Media Law (2013), p. 81.

${ }^{27}$ See e.g. D. Voorhoof, 'The Right to Freedom of Expression and Information under European Human Rights System: Towards a more Transparent Democratic Society’ EUI Working Paper RSCAS 2014/12, p. 13; K. Steyn and H. Slarks, 'Positive Obligations to Provide Access to Information under the European Convention on Human Rights' 17 Judicial Review (2012), p. 315.

28 The ECtHR itself describes the evolution as 'gradual clarification', see ECtHR, Magyar Helsinki Bizottság v. Hungary, para. 127.

${ }^{29}$ ECtHR, Leander v. Sweden.

${ }^{30}$ ECtHR, Gaskin v. The United Kingdom, Judgment of 7 July 1989, Application No. 10454/83; ECtHR, Guerra and Others v. Italy, Judgment of 19 February 1998, Application No. 14967/89, GC. See more W. Hins and D. Voorhoof, '3 EuConst (2007), p. 117-120.

${ }^{31}$ ECtHR, Sdruženi Jihočeské Matky v. Czech Republic, Decision of 10 July 2006, Application No. 19101/03.

32 ECtHR, Timpul Info-Magazin and Anghel v. Moldova, Judgment of 27 November 2007, Application No. 42864/05. The question under Article 10 ECHR concerned the freedom of expression of the press to impart ideas
} 
documents under Article 10 ECHR. ${ }^{33}$ Importantly, the ECtHR pointed out that it is generally on the way towards a broader interpretation of the notion of the 'freedom to receive information' under Article 10 ECHR and, as a consequence, towards the recognition of a right of access to information. ${ }^{34}$

Finally, the time was ripe for the explicit recognition of the right of access to public documents within Article 10 ECHR. ${ }^{35}$ When the route was finally clear for the recognition of the right of access to information under Article 10 ECHR, the ECtHR continually chose to strengthen it, for example, by imposing an obligation upon states to provide the information in question. ${ }^{36}$ There were, however, some examples where the ECtHR has taken a few steps backwards with the protection of the right of access to public documents. ${ }^{37}$ After these seeming aberrations, the Grand Chamber of the ECtHR recognised fully a right of access to public documents and then continued to develop its substance. ${ }^{38}$

\section{B. The scope of the right of access to information under Article 10 ECHR}

In Magyar Helsinki Bizottság, the ECtHR enunciated in detail its mechanism for dealing with the right of access to information under Article 10 ECHR. ${ }^{39}$ The ECtHR laid down specific criteria that define the precise scope of the right of access to information. These criteria are: (i) the purpose of the information request; (ii) the nature of the information sought; (iii) the role of the applicant; and (iv) ready and available information. ${ }^{40}$

\section{The purpose of the information request}

The emphasis here is on whether the gathering of the information is a relevant preparatory step in journalistic activities or in other activities creating a forum for public debate. In this context, the ECtHR has provided that in the area of press freedom, there are duties and responsibilities inherent in the exercise of the freedom of expression to journalists in relation to reporting on issues of general interest. This means that the journalists must act in good faith in order to provide accurate and reliable information in accordance with the ethics of journalism. Consequently, the same considerations apply to an NGO assuming a social watchdog function. Therefore, in order for Article 10 ECHR to come into play, it must be ascertained whether the information sought was in fact necessary for the exercise of freedom of expression. According

and opinions on political matters and on other matters of public interest. On the case, see O. Andreotti et al (eds.), Journalism at risk, p. 120.

${ }^{33}$ ECtHR, Társaság a Szabadságjogokért v. Hungary, Judgment of 14 April 2009, Application No. 37374/05.

${ }^{34}$ ECtHR, Társaság a Szabadságjogokért v. Hungary, para. 35.

${ }^{35}$ ECtHR, Gillberg v. Sweden, Judgment of 3 April 2012, Application No. 41723/06, GC, para. 93; ECtHR, Youth Initiative for Human Rights v. Serbia, Judgment of 25 June 2013, Application No. 48135/06, para. 20.

${ }^{36}$ ECtHR, Österreichische Vereinigung zur Erhaltung, Stärkung und Schaffung eines wirtschaftlich gesunden land- und forstwirt-schaftlichen Grundbesitzes v. Austria, Judgment of 28 November 2013, Application No. 39534/07; ECtHR, Roşiianu v. Romania, Judgment of 24 June 2014, Application No. 27329/06; ECtHR, Guseva v. Bulgaria, Judgment of 17 February 2015, Application No. 6987/07. On the discussion on whether there is a general right of access to documents under Article 10 ECHR, see e.g. F. Leghe and P. Weismann, 'The European Court of Human Rights and Access to Information' 3 IHRLR (2014), p. 313-314.

${ }^{37}$ ECtHR, Shapovalov v. Ukraine, Judgment of 31 July 2012, Application No. 45835/05; ECtHR, Friedrich Weber v. Germany, Decision of 6 January 2015, Application No. 70287/11; ECtHR, Bubon v. Russia, Judgment of 7 February 2017, Application No. 63898/09.

${ }^{38}$ ECtHR, Magyar Helsinki Bizottság v. Hungary. See comment of the case, S. Parmar, 'Affirming the right of access to information in Europe: the Grand Chamber decision in Magyar Helsinki Bizottsag v. Hungary' EHRLR (2017).

39 The ECtHR has created these criteria in its case law also before but now it explicitly elaborates them further.

${ }^{40}$ ECtHR, Magyar Helsinki Bizottság v. Hungary, para. 157-170. 
to the ECtHR, obtaining access to information would be considered necessary if withholding it would hinder or impair the individual's exercise of his right to freedom of expression. ${ }^{41}$

\section{The nature of the information sought}

The information requested must also in the public interest. According to ECtHR jurisprudence, such recognised categories of public interest are inter alia the use of electronic surveillance measures,${ }^{42}$ information about a constitutional complaint, ${ }^{43}$ original documentary sources for legitimate historical research ${ }^{44}$ and decisions concerning real property transaction commissions. ${ }^{45}$ More precisely, the information, data or documents to which access is sought must generally meet a public-interest test in order to prompt a need for disclosure under Article 10 ECHR. Such a need may exist where, for example, 'disclosure provides transparency on the manner of conduct of public affairs and on matters of interest for society as a whole and thereby allows participation in public governance by the public at large' ${ }^{46}$

The definition of what might constitute the public interest in this context will depend on the circumstances of each case. The ECtHR emphasises, first, that the public interest relates to matters which 'affect the public to such an extent that it may legitimately take an interest in them, which attract its attention or which concern it to a significant degree, especially in that they affect the well-being of citizens or the life of the community ${ }^{47}$. Secondly, public interest is involved in matters which 'are capable of giving rise to considerable controversy, which concern an important social issue, or which involve a problem that the public would have an interest in being informed about' ${ }^{48}$ In sum, the public interest is defined rather broadly by the ECtHR. The ECtHR, however, has stated that the public interest cannot be reduced to the public's thirst for information about the private life of others, or to an audience's wish for sensationalism or even voyeurism.

Therefore, in order to ascertain whether the publication relates to a subject of general importance, it is necessary to assess the publication as a whole. In this respect, the privileged position is given to political speech and debate on issues of the public interest. As a result, the ECtHR militates in favour of affording a right of access to such information held by public authorities. $^{49}$

\section{The role of the applicant}

Special importance is given to the question: who is seeking the information. The ECtHR has given particular weight to the applicant's role as a journalist ${ }^{50}$ or as a social watchdog NGO whose activities related to matters of public interest. ${ }^{51}$ The ECtHR has outlined that when an NGO draws attention to matters of public interest, it is exercising a public watchdog role

\footnotetext{
${ }^{41}$ Ibid., para. 158-159.

${ }^{42}$ ECtHR, Youth Initiative for Human Rights v. Serbia, para. 24.

${ }^{43}$ ECtHR, Társaság a Szabadságjogokért v. Hungary, para. 37-38.

${ }^{44}$ ECtHR, Kenedi v. Hungary, Judgment of 26 May 2009, Application No. 31475/05, para. 43.

${ }^{45}$ ECtHR, Österreichische Vereinigug v. Austria, para. 42.

${ }^{46}$ ECtHR, Magyar Helsinki Bizottság v. Hungary, para. 161.

${ }^{47}$ Ibid., para. 162.

48 Ibid.

${ }^{49}$ Ibid., para. 162-163.

${ }^{50}$ See e.g. ECtHR, Roşiianu v. Romania, para. 61.

${ }^{51}$ See e.g. ECtHR, Társaság a Szabadságjogokért v. Hungary, para. 36; ECtHR, Österreichische Vereinigung v. Austria, para. 35; ECtHR, Youth Initiative for Human Rights v. Serbia, para. 20; ECtHR, Guseva v. Bulgaria, para. 41.
} 
similar importance to that of the press. The ECtHR has also named the role of the NGO as 'social watchdog'. 52

The thrust of the ECtHR's arguments with respect to this issue is, therefore, that: 'Given that accurate information is a tool for their trade, it will often be necessary for persons and organisations exercising watchdog functions to gain access to information in order to perform their role of reporting on matters of public interest. ${ }^{53}$ Referring to effectiveness, the ECtHR also provides that: 'Obstacles created in order to hinder access to information may result in those working in the media or related fields no longer being able to assume their 'watchdog' role effectively (...). ${ }^{54}$ The ECtHR goes on to conclude that the role of a public watchdog is not left only to the press and NGOs. Academic researchers, authors of literature on matters of public concern, bloggers and even popular users of social media may be subsumed within this category of 'public watchdogs' ${ }^{55}$ Consequently, the scope of application of the role of the applicant is quite broad.

\section{Ready and available information}

The 'ready and available' information constitutes an important criterion in the overall assessment of whether a refusal to provide the information can be regarded as an interference with the freedom to receive and impart information as protected by Article 10 ECHR. For example, the criterion is linked to certain positive obligations: the information requested must be ready and available, meaning that the public authorities do not have duties to collect any data. The ECtHR has repeated several times that the right to receive information cannot be construed as imposing on a state positive obligations to collect and disseminate information of its own motion. ${ }^{56}$ Further, the ECtHR has explicitly ruled that Article 10 ECHR does not impose an obligation to collect information upon the applicant's request, particularly when a considerable amount of work is involved. ${ }^{57}$

\section{The public interest argumentation of the ECtHR}

The right of access to information is by no means absolute. Paragraph 2 of Article 10 ECHR provides explicit limitations upon the right which means that, for example, the rights of others or public safety are legitimate aims that may limit the right of access to documents when it is 'necessary in a democratic society'. ${ }^{58}$ The ECtHR must, therefore, often balance the right of access to documents against other rights (for example, personal data protection). In these cases, the public interest is essential as a means of defining how strong the right of access to information is in that particular case. If the ECtHR considers that there is a considerable public

\footnotetext{
52 ECtHR, Társaság a Szabadságjogokért v. Hungary, para. 27; ECtHR, Youth Initiative for Human Rights v. Serbia, para. 20; ECtHR, Österreischische Vereinigung v. Austria, para. 34.

${ }^{53}$ ECtHR, Magyar Helsinki Bizottság v. Hungary, para. 167.

${ }^{54}$ Ibid. [emphasis added].

${ }^{55}$ Ibid., para. 168.

${ }^{56}$ ECtHR, Leander v. Sweden, para. 74; ECtHR, Gaskin v. The United Kingdom, para. 52; ECtHR, Guerra and Others v. Italy, para. 53; ECtHR, Roche v. The United Kingdom, Judgment of 19 October 2005, Application No. 32555/96, para. 172; ECtHR, Magyar Helsinki Bizottság v. Hungary, para. 156.

${ }^{57}$ ECtHR, Weber v. Germany, para. 25; ECtHR, Bubon v. Russia, para. 45.

${ }^{58}$ Article 10(2) ECHR provides: 'The exercise of these freedoms, since it carries with it duties and responsibilities, may be subject to such formalities, conditions, restrictions or penalties as are prescribed by law and are necessary in a democratic society, in the interests of national security, territorial integrity or public safety, for the prevention of disorder or crime, for the protection of health or morals, for the protection of the reputation or rights of others, for preventing the disclosure of information received in confidence, or for maintaining the authority and impartiality of the judiciary.'
} 
interest behind the information request concerned, then the ECtHR will be more likely to rule in favour of the right of access to information.

In order for the right of access to information to exist, the ECtHR stresses that the information requested must, in some manner, be in the public interest. The concept of the public interest is understood broadly by the ECtHR: it relates to matters which affect the public to such an extent that it may legitimately take an interest in them (especially when they affect the well-being of citizens or the life of the community) as well as matters which are capable of giving rise to considerable controversy (in other words, those that concern an important social issue or which involve a problem that the public would have an interest in being informed about). ${ }^{59}$

The public interest is the key mechanism by which the ECtHR can decide the extent of the right of access to information in a specific case. The ECtHR argues with respect to the public interest both when deciding whether there has been an interference with the right to freedom of expression and whether the interference is justified for the protection of a legitimate aim and as being 'necessary in a democratic society'. For example, in Magyar Helsinki Bizottság, when evaluating whether there was an interference with the right of access to information, the ECtHR adopted public interest argumentation: the information request concerning the functioning of the public defenders' scheme was of 'obvious public interest'. ${ }^{60}$ Moreover, when deciding whether the interference was justified, the ECtHR assumed a public interest point of view in its argumentation:

(...) the subject matter of the survey concerned the efficiency of the public defenders system (...). This issue was closely related to the right to a fair hearing, (...) a right of paramount importance under the Convention. Indeed, any criticism or suggested improvement to a service so directly connected to fair-trial rights must be seen as a subject of legitimate public concern. (...) The issue under scrutiny thus going to the very essence of a Convention right, the Court is satisfied that the applicant NGO intended to contribute to a debate on a matter of public interest. ${ }^{61}$

By stressing counter arguments concerning the protection of personal data of the public defenders, the ECtHR has emphasised that the information requested related predominantly to the conduct of professional activities in the context of public proceedings. In short, public defenders' professional activities cannot be considered to be a private matter. ${ }^{62}$ Consequently, the ECtHR found that there was a violation of Article 10 ECHR. In this case, the public interest related to the fair-trial rights that are protected under Article 6 ECHR. Frankly, it is hard to find a more important public interest than the protection of fair-trial rights that form a necessary pre-condition for the rule of law.

In Österreichische Vereinigung, the ECtHR also referred to public interest argumentation. First, when ruling on whether there had been interference, the ECtHR paid attention to the nature of the NGO's information request: '(...) it wished to obtain information about the decisions of the Commission, that is to say the appellate authority approving or refusing transfers of agricultural and forest land under the Tyrol Real Property Transactions Act. The

\footnotetext{
${ }^{59}$ ECtHR, Magyar Helsinki Bizottság v. Hungary, para. 162.

${ }^{60}$ Ibid., para. 180.

${ }^{61}$ Ibid., para. 197.

62 Ibid., para. 194.
} 
aims pursued by that Act (...) are subjects of general interest. ${ }^{63}$ Furthermore, the ECtHR concludes that the applicant association was therefore involved 'in the legitimate gathering of information of public interest'. ${ }^{64}$ Secondly, the public interest argumentation was relevant when weighing whether the interference was justified. In this case, the nature of the information and the public interest behind it was decisive. The information requested was not 'ready and available' but, in spite of this, the ECtHR still held that there had been a violation of Article 10 ECHR when refusing to disclose the information. The ECtHR stated that the information which was requested from the national authorities concerned decisions on disputes over 'civil rights' within the meaning of Article 6 ECHR and which must, therefore, be seen as being of 'considerable public interest'. ${ }^{65}$ In this case, the considerable public interest overrode the criterion of 'ready and available' aside.

Public interest argumentation was also decisive for the ECtHR in deciding whether there had been an interference in the case of Társaság. Here, the Court held that the requested information concerned the constitutionality of criminal legislation on the topic of drug-related offences, which 'undoubtedly constituted a matter of public interest'. ${ }^{66}$ There was, therefore, an interference with the applicant's rights under Article 10 ECHR. The ECtHR then went on to utilise public interest argumentation in deciding whether the interference was justified. As a starting point, the ECtHR underlined that the obstacles placed in the way of the proper functioning of the press by the authorities calls for the 'most careful scrutiny' of the situation. ${ }^{67}$ The ECtHR then went on to provide that: ' $(\ldots)$ the State's obligations in matters of freedom of the press include the elimination of barriers to the exercise of press functions where, in issues of public interest, such barriers exist solely because of an information monopoly held by the authorities. ${ }^{68}$ Further, the ECtHR took a very practical standpoint by stating that: ' (...) the obstacles created in order to hinder access to information of public interest may discourage those working in the media or related fields from pursuing such matters. ${ }^{69}$ Accordingly, there was a violation of Article 10 ECHR. This case perfectly illustrates the importance of the exercise of press functions vis-à-vis public interest in the ECHR system.

Limiting the right of access to information to the realm of public interest gives rise to both conceptual and practical difficulties. At a conceptual level, such a limitation does not sit well with one of the basic principles of information access laws: that access rights are held by everyone, regardless of their capacity to establish any particular interest in accessing the requested information. ${ }^{70}$ Further, from a practical perspective, it is not always possible to know beforehand whether or not the information that is requested contributes to the debate on issues that are in the public interest. It is also important to keep in mind that publicity in itself already promotes the legitimacy of public institutions, regardless of whether the information in a particular case is of 'obvious' or 'considerable' public interest. Further, the definition of public interest is vague: what is not understood as being a matter of public interest today may be seen as more significant in the future when other circumstances, such as connections between persons and organisations, have been made public. ${ }^{71}$ The ECtHR, however, defines the public interest in a very broad way. The issue of the public interest determining the scope of

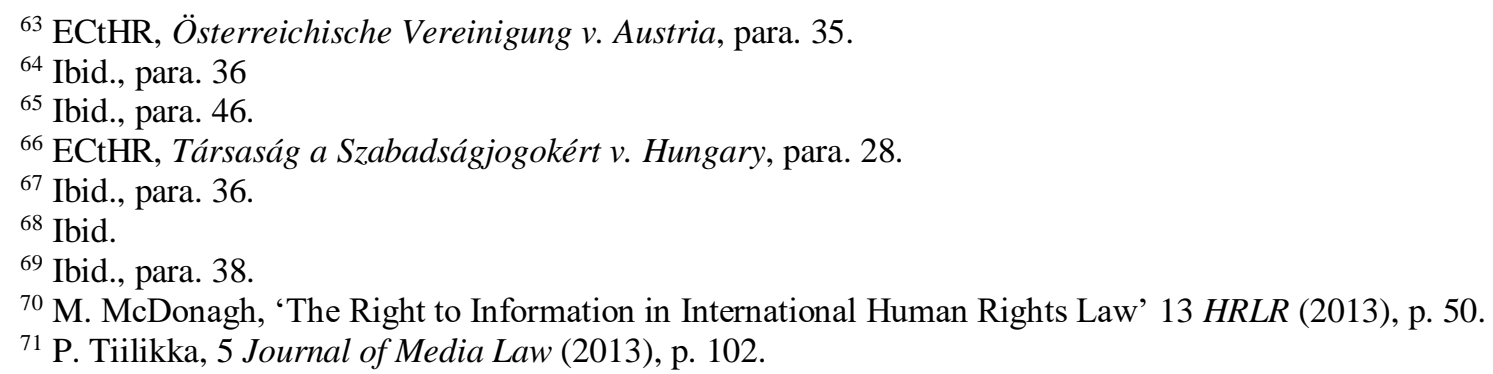


application of the right of access to information is, therefore, not particularly problematic. Further, in hard cases when the right of access to information is weighed against, for example, personal data protection or the duties of the state, the ECtHR needs some kind of yardstick to measure how wide the right of access to information should be in that particular case. The public interest behind the information request is but one element which needs to be evaluated when determining the breadth of the right.

\section{The right of access to documents in EU law}

\section{A. The legal framework of the right to access to documents under EU law}

In contrast to the European Convention regime described above, the EU places explicit and significant emphasis upon access to documents. According to Article 15 TFEU, every EU citizen or resident has a right of access to documents of the 'Union's institutions, bodies, offices and agencies'. The same right is also enshrined in Article 42 of the Charter, profoundly highlighting the importance afforded to the principle of institutional transparency in the modern EU democratic system. From a more practical operational legal perspective, the most significant piece of EU legislation in the field of public access to documents came in 2001 in the form of Regulation 1049/2001.

Regulation 1049/2001, enacted pre-Lisbon and now outdated in a number of important respects ${ }^{72}$ sets-out an ostensibly expansive access to documents regime applicable to the EU institutions and its agencies. It was brought to life to 'give the fullest possible effect to the right of public access to documents' ${ }^{73}$ so that, effectively, 'all documents of the institutions should be accessible'. ${ }^{74}$ On top of this general strong principle of openness, Regulation 1049/2001 further emphasises that documents relating to legislative matters should be even more openly available than other documents. ${ }^{75}$

The scope of the EU's right to access to documents according to Regulation 1049/2001 also appears, at least on its face, wider - or, perhaps more accurately, less restrictive - than that of the European Convention's right of access to information detailed above. For example, the applicant does not need to show that the release of the document being requested is 'in the public interest' to obtain access to that document (outside of the operation of the overriding public interest in disclosure, which is discussed below and forms the core of this contribution), presumably because the transparency of the EU institutions is viewed as something that is inherently in the public interest in the EU. ${ }^{76}$ The wide nature of the right of access to documents is also complemented by the generous way in which Article 3(a) of Regulation 1049/2001 defines 'document' as 'any content whatever its medium ... concerning a matter relating to the policies, activities and decisions falling within the institution's sphere of responsibility'. However, despite the seemingly prima facie expansive nature of the public right of access to documents, Regulation 1049/2001 expressly recognises that not all documents should be

\footnotetext{
${ }^{72}$ See e.g. D. Curtin and P. Leino, 'Openness, Transparency and the Right of Access to Documents in the EU' Indepth for forlysis Pe Committee www.europarl.europa.eu/RegData/etudes/IDAN/2016/556973/IPOL_IDA(2016)556973_EN.pdf, p. 26.

${ }^{73}$ Recital 4 of Regulation 1049/2001.

${ }^{74}$ Ibid., recital 11.

75 Ibid., recital 6.

${ }^{76}$ See recital 2 of Regulation 1049/2001.
} 
necessarily accessible by the public and therefore carves out a series of exceptions to the general principle of widest possible access that are grouped into two general categories. ${ }^{77}$

The first category of exceptions are mandatory, meaning that if any apply to a document in a given instance then that document must not be disclosed by the institution that holds the document, even if the institutions receiving the request was of the opinion that it would be preferable to disclose the document. ${ }^{78}$ The mandatory exceptions seek to protect public security, defence and military matters, international relations, the financial, monetary or economic policy of the EU or a Member State and finally the privacy and integrity of the individual. ${ }^{79}$ Although fascinating in their own right, the mandatory exceptions will not be discussed any further in this contribution. ${ }^{80}$

The second category of exceptions, on the other hand, are discretionary. This group of exceptions includes inter alia situations where release of a document would undermine the commercial interests of a natural or legal person, the purpose of inspections, investigations or audits or where the release of a document relating to a decision yet to be taken by an institution would seriously undermine the protection of that institution's decision-making process. ${ }^{81}$ Relying on a logic different to the mandatory exceptions noted above, when applying these exceptions the institutions can refuse access to a document based upon them unless an OPID exists with respect to the document. What this means in practice is that if an institution considers that any of these exceptions apply to a document they must still determine whether a public interest in disclosure exists and then weigh that interest against the harm that might result to the interest protected by the exception. The existence of an OPID can, therefore, compel the institutions to disclose a document even if harm might still occur to one of the protected interests. In this way, the theoretical power of the OPID is considerable.

The discretionary exceptions can be understood, therefore, to effectively be an analogue of the ECHR access to information system. In other words, the ECHR regime requires the applicant to show the public interest in the release of the document and the public authority to show that, regarding a document's non-disclosure, there is a legitimate aim and that it is 'necessary in a democratic society'. With respect to the Regulation 1049/2001 system, on the other hand, the EU institutions' legitimate secrecy aims are enshrined as an exhaustive list of exceptions to disclosure with the possibility for an OPID to override their operation. In both instances, the effective 'public interests' must ostensibly be weighed up to determine which one, in the end, wins out. The concept of the public interest is, therefore, determinative as to the ultimate disclosure of any documents at issue in a concrete case.

One would therefore expect, for the reasons outlined previously regarding Article 52(3) concerns, that the public interest reasoning utilised by the ECtHR with respect to the balancing of these two inherently dichotomous positions of secrecy and openness would be at the very least substantively considered - if not followed-by the CJEU when they decide matters relating to the discretionary exceptions. This has, however, distinctly not been the case. For a

\footnotetext{
${ }^{77}$ Ibid., Article 1(a).

${ }^{78}$ For a discussion on the mandatory exceptions, see D. Adamski, "How wide is the "widest possible"? Judicial interpretation of the exceptions to the right of access to official documents revisited', 46 CMLR (2009), p. 52329.

${ }^{79}$ Article 4(1) of Regulation 1049/2001.

${ }^{80}$ Interestingly with respect to the mandatory exceptions, it appears possible to make the argument that they almost invariably cannot be compatible with the ECtHR's freedom of information regime because a consideration of the public interest does not factor into whether or not the documents should be disclosed.

${ }^{81}$ Articles 4(2), (3) and (4) of Regulation 1049/2001.
} 
judicial organ that is at least theoretically required to match its standards against those created by the ECtHR in respect of situations such as the one at hand, the CJEU's express failure to do so is disappointing.

Nevertheless, in order to determine then whether the CJEU's understanding of the operation of the discretionary exceptions issues can in fact be understood to correspond with the interpretation of Article 10 of the ECHR by the ECtHR, it is first necessary to determine how the notion of the OPID has been interpreted. The next section, therefore, looks at some of the case law relevant to understanding this issue.

\section{B. The CJEU's handling of the overriding public interest in disclosure}

The CJEU's approach to dealing with OPID issues in access to documents cases has undergone significant evolution throughout its life-cycle. Starting out on footing arguably substantively similar to that found in the ECtHR's current Article 10 jurisprudence, the OPID has effectively developed into a concept that has little to no practical operation for citizens seeking to obtain institutional documents, placing it now in stark contrast with the ECHR regime.

The case of Turco provides the most illustrative example of the the Court's early jurisprudence on the matter. ${ }^{82}$ It concerned the applicant, Mr Turco, who requested a number of documents from the Council, including a legal opinion of the Council's Legal Service on the topic of a directive concerning minimum standards for the reception of asylum seekers. Refusing to disclose the document, the Council argued that its release would undermine the protection of legal advice, which is a protected interest pursuant to Article 4(2) of Regulation 1049/2001. Disagreeing with the Council's refusal to disclose the document, Mr Turco submitted a confirmatory application to the Council, arguing inter alia that 'the principle of democracy and citizen participation in the legislative process constitutes an overriding public interest in disclosure of, inter alia, the legal opinion in question' ${ }^{83}$ Replying to Mr Turco's confirmatory application, the Council, still refusing to disclose the requested document, argued that the overly general notion of increased transparency and openness cannot constitute an OPID. To do so, the Council argued, would have the effect that all documents of a similar nature would be rendered automatically disclosable, essentially depriving the Article 4(2) exception of its practical effect. ${ }^{84}$ Although unsuccessful at first instance, the ECJ on appeal was substantially more receptive to the arguments put forward by $\mathrm{Mr}$ Turco, particularly with respect to the OPID.

The ECJ ultimately held that the Council had erred in its assessment and, in fact, the document was indeed subject to an OPID. Providing a strong statement on the matter, the ECJ enunciated that:

an overriding public interest is constituted by the fact that disclosure of documents containing the advice of an institution's legal service on legal questions arising when legislative initiatives are being debated increases the transparency and openness of the legislative process and strengthens the democratic right of European citizens to scrutinize the information which has formed the basis of a legislative act. ${ }^{85}$

\footnotetext{
${ }^{82}$ Joined Cases C-39/05 P and C-52/05 P Sweden and Maurizio Turco v. Council, para. 12.

83 Ibid., para. 12.

84 Ibid., para. 13.

${ }^{85}$ Ibid., para 67.
} 
Essentially on the basis of the above analysis, the ECJ went on to provide that legal advice concerning a legislative process is prima facie disclosable. ${ }^{86}$ In reaching this conclusion, it is clear that the ECJ weighed this OPID against the Council's interest in keeping the legal advice secret pursuant to the relevant exception to disclosure. ${ }^{87}$ The evolution of the concept of the OPID began, therefore, upon a relatively wide and flexible public interest paradigm where the ECJ clearly engaged in a substantive interest balancing exercise, even if the actual reasoning given in the decision was not substantial.

However, this manner of conceiving the OPID was almost immediately changed. In decisions in cases such as API ${ }^{88}{ }^{2} P N^{89}$ and ClientEarth, ${ }^{90}$ the nature of the interpretation of the concept was significantly altered by the burden of proving the existence of the OPID essentially being placed upon the applicant for documents. Therefore, for an applicant to now be able to utilise the OPID in a particular case and therefore open up the decision of an institution to not disclose a document according to a discretionary exception, they must be able to 'refer to specific circumstances that establish such an overriding public interest', with 'general considerations' being insufficient 'for that purpose of establishing that an overriding public interest prevails over the reasons justifying the refusal to disclose the documents' ${ }^{91}$

The case law on this matter, however, demonstrates that the 'specific circumstances' threshold is a heavy burden, with no applicant for documents having successfully crossed the threshold since the test's introduction. Indeed, Curtin and Leino have argued that such a standard is effectively impossible to meet, a conclusion with which we agree. ${ }^{92}$ The reason for this is that it seems that, on an analysis of the post-Turco case law on the matter, what the CJEU requires on the part of the applicant is actual knowledge of the document that they are seeking. This conclusion is backed-up by the fact that, as far as we are aware, the only case in which an OPID has been successfully argued for since Turco-which, as discussed, had a more 'liberal' OPID test - is the General Court (GC) case of Pari Pharma. ${ }^{93}$ However, in Pari Pharma, the party arguing for the existence of an OPID was the EU agency that had produced the documents and had, therefore, full knowledge of their contents. The CJEU's jurisprudence in this respect contains, therefore, the unavoidable practical paradox that an applicant for documents must argue specifics about a document that they have never seen, a proposition that defies the logic of a document access request in the first place.

\section{Assessing the corresponding nature of the relevant rights}

With an understanding now of how the CJEU has come to interpret the notion of the OPID, we can engage in the exercise of trying to determine whether these comparable access to information rights, as understood through the prism of each court's dealing with the public

\footnotetext{
${ }^{86}$ Ibid, para. 68-69.

${ }^{87}$ Ibid., para. 67.

88 Joined Cases C-514/07 P, C-528/07 P and C-532/07 P Sweden and others v. Association de la presse internationale ASBL (API) and Commission, EU:C:2010:541.

89 Joined Cases C-514/11 P and C-605/11 P Liga para a Protecção da Natureza (LPN) v. Commission, EU:C:2013:738.

${ }^{90}$ Case C-612/13 P ClientEarth v. Commission, EU:C:2015:486.

${ }^{91}$ Case T-755/14 Herbert Smith Freehills LLP v. Commission, EU:T:2016:482, para. 69, where the General Court paraphrases the relevant CJEU jurisprudence on the matter.

92 D. Curtin and P. Leino, 54 CMLR (2017), p. 1707.

${ }^{93}$ Case T-235/15 Pari Pharma GmbH v. European Medicines Agency, EU:T:2018:65.
} 
interest, 'correspond' pursuant to Article 52(3) of the Charter. As stated above, we consider that the right of access to documents provided by Article 42 Charter corresponds to the right of access to information provided by Article $10 \mathrm{ECHR}$ within the meaning of Article 52(3) Charter. Perhaps unsurprisingly, the CJEU's restrictive OPID interpretation in the context of the discretionary exceptions does not appear to 'match-up' with the ECtHR's access to information regime, which, we argue, is a significant problem. For ease of understanding, the analysis in this part will be conducted by reference to the four ECtHR access to information criteria detailed in Section 2 of this contribution.

The first relevant public interest criterion noted is that of the purpose of the information request. Pursuant to the ECtHR regime, this is an important element in that the relevant information sought must be necessary to exercise a person's freedom of expression. However, the ECtHR has emphasised here that the gathering of information is important from the point of view of journalistic activities generally or for 'creating a forum for, or constituting an essential element of, public debate'. ${ }^{94}$ On the other hand, the CJEU with respect to the OPID has held that the reason for obtaining the documents cannot be the applicant's purely private or individual interest or interests. For example, an applicant seeking to use documents for their own action for damages ${ }^{95}$ or claiming that the information is necessary to be able to pursue an action against the institutions of the $\mathrm{EU}^{96}$ are private or individual interests and therefore cannot found an OPID. To the CJEU, the interest or interests grounding an OPID 'must be objective and general in nature and must not be indistinguishable from individual or private interests' ${ }^{97}$ Given the emphasis placed by the ECtHR on the public nature of the purpose for the information request, we argue that the two courts' understandings with respect to this criterion appear largely to intersect.

Secondly, we can look to the role of the applicant in each of the transparency systems. The ECtHR model finds that the question of who is seeking the information is also a significant factor in the public interest calculation. With respect to the Regulation 1049/2001 OPID, however, the CJEU has held that, at the very least, the identity of the applicant-for example, an environmental NGO seeking documents in accordance with its governing documents-is not sufficient in and of itself to ground an OPID. ${ }^{98}$ However, the relevant authorities are unclear as to whether the identity of the applicant is something to be factored generally into the OPID calculation. Regarding this matter, the CJEU can actually be seen to be arguably somewhat fairer in their approach than the ECtHR: it seems a reasonable conclusion that the identity of the person requesting documents should not necessarily impact their ability to obtain documents in the public interest.

The third criterion, that of the information being ready and available, seems largely comparatively uncontroversial. That is, the information needing to be in this form under the ECHR system appears to be essentially comparable with the scope of Regulation 1049/2001,

\footnotetext{
${ }^{94}$ ECtHR, Magyar Helsinki Bizottság v. Hungary, para. 158.

${ }^{95}$ Case T-403/05 MyTravel Group plc v. Commission, EU:T:2008:316, para. 65.

96 Case T-181/10 Reagens SpA v. Commission, EU:T:2014:139, para. 142. Also see e.g., Case C-404/10 P Commission v. Éditions Odile Jacob SAS, EU:C:2012:393, para. 144-146.

${ }^{97}$ Case T-403/05 MyTravel Group plc v. Commission, para. 65.

98 See e.g., Joined Cases C-514/11 P and C-605/11 P Liga para a Protecção da Natureza (LPN) v. Commission, para. 95; Case T-727/15 Association Justice \& Environment z.s. v Commission, EU:T:2017:18, para. 59.
} 
which applies to 'all documents held by an institution, that is to say, documents drawn up or received by it and in its possession'. It is hard to find any meaningful difference between the two systems as regards this area of assessment.

Finally, and perhaps determinatively from the point of view of Article 52(3) of the Charter, is the differing jurisprudence relating to the nature of the information sought. Firstly, it seems clear that, according to ECtHR case law, the nature of the information is regarded as perhaps the central issue in the public interest calculation matrix. The importance placed upon this criterion is quite logical because, after all, the essential or fundamental thing being assessed from the point of view of the notion of the public interest is the information that a person is seeking to have disclosed. Importantly, however, it is with respect to this issue that we can see most starkly how the CJEU's restrictive OPID interpretation has made the two courts' public interest reasoning truly different. By reversing the burden of proof in OPID matters, the CJEU has created a situation whereby the case law relating to the nature of the information has remained entirely undeveloped. In other words, because the CJEU refuses, in the absence of the raising of 'specific circumstances' by the applicant, to engage in substantive public interest balancing, the court does not even reach the point of debating whether the nature of the information justifies its release pursuant to the OPID.

The disparate nature of the different courts' jurisprudence on this issue can be seen repeatedly in the CJEU's treatment of the OPID. For example, in cases involving documents concerning such issues as public finances, ${ }^{99}$ potential breaches of environmental laws by Member State governments ${ }^{100}$ and public health, ${ }^{101}$ the CJEU, for the burden of proof reasons outlined above, did not open up the discussion about how or whether the nature of the information affects the existence of an OPID. This is despite the fact that it is arguably exactly these kinds of documents that warrant some type of a conversation of that nature by the court. The ECtHR, on the other hand and as discussed, explicitly 'attaches weighty consideration to the presence of particular categories of information considered to be in the public interest'. ${ }^{102}$

We argue that it seems quite clear that the way in which the CJEU currently interprets the concept of the OPID essentially means that standard of correspondence of rights outlined in Article 52(3) of the Charter cannot be met. Although three of the four criteria do not appear problematic in the circumstances, the fourth and arguably most important - the nature of the information in the public interest calculation - do not 'correspond' in practice between the two courts. Without actually engaging in an act of balancing the public interest or interests in the release of the information against the interests of the institution in keeping the documents secret, the CJEU cannot be understood to meet the standard set by the ECtHR.

\section{Analysis and critique}

As can be seen, the public interest argumentation utilised by the ECtHR in access to documents cases differs substantially from the CJEU's approach. Of course, it must be recognised that the interpretative angle and context regarding the public interest is somewhat different between the

\footnotetext{
${ }^{99}$ Case C-477/10 P Commission v. Agrofert Holding a.s., EU:C:2012:394.

100 Joined Cases C-514/11 P and C-605/11 P Liga para a Protecção da Natureza (LPN) v. Commission.

${ }^{101}$ Case C-562/14 P Sweden v. Commission, EU:C:2017:356.

${ }^{102}$ ECtHR, Magyar Helsinki Bizottság v. Hungary, para. 160.
} 
systems. The ECtHR has a well-established jurisprudence concerning freedom of expression rights under Article 10 ECHR where the emphasis has been upon the protection of freedom of expression rights especially when there is a public interest involved. ${ }^{103}$ The ECtHR uses public interest evaluation to determine the extent of the right of access to documents and to decide whether the public interest in transparency overrides the explicitly protected interests of institutional secrecy. Additionally, the public interest behind the information request is given special weight when determining possible positive obligations derived from the right of access to documents. With respect to the CJEU, however, the evaluation of the public interest is viewed from a slightly different perspective: whether there is a public interest in disclosing the documents in question that overrides the application of a discretionary exception to disclosure.

The differences relating to the public interest argumentation by these two courts is well revealed if we take legislative procedures in focus. The ECJ held in Turco that-due in part to the existence of an OPID-there is a prima facie obligation to disclose legal opinions drafted in the context of legislative procedures even if disclosure could undermine the protection of legal advice. ${ }^{104}$ However, the GC in the more recent case of $H S F$ effectively stated, on the basis of post-Turco ECJ cases such as API and $L P N$, that the fact that a document contains legal advice drafted in the context of a legislative process is merely a 'general consideration' upon which an OPID cannot be based. ${ }^{105}$ No substantive balancing of relevant interests was therefore undertaken by the GC in $H S F$, despite the ECJ doing just this in Turco, a case involving very similar facts. The restrictive effect of the 'specific circumstances' test developed by the CJEU after Turco becomes, therefore, quite visible. The ECtHR, by contrast, gives special weight to the applicant's ability to participate in 'a meaningful manner' in the legislative process when concluding that the refusal to disclose the information requested was not justified. ${ }^{106}$ Further, the ECtHR has stressed the public interest related to applicant's purpose to contribute to the public debate concerning legislation on drug-related offences, and thereby, finding a violation of Article 10 ECHR. ${ }^{107}$

We argue, therefore, that the CJEU's post-Turco approach to the OPID is rather conservative when one considers that it does not independently - that is, without relevant evidence being produced by an applicant for documents - engage in a public interest balancing exercise. Without having read the case law, it seems safe to assume that the CJEU would, as a matter of course in access to documents cases, evaluate substantively whether there is a public interestor multiple - that would override the institutions appeal to the exceptions to disclosure without needing this to be necessarily 'proved' by the applicant. By contrast, the CJEU sees that it is the applicant who must in fact somehow show, with specific evidence, that there is an OPIDin this way, it does not develop any public interest argumentation outside of this closed paradigm. As noted above, such an approach is distinctly at odds with the ECtHR's much more pragmatic approach to the notion of the public interest.

The CJEU's treatment of the OPID as it relates to Article 52(3) of the Charter is also highlighted when one considers how case law of the ECtHR has been dealt with in the context of Regulation 1049/2001 access to documents cases. Notably, engagement with ECtHR jurisprudence by the CJEU in this area is generally rare, and invariably

\footnotetext{
${ }^{103}$ See e.g. ECtHR, Sunday Times v. The United Kingdom, Judgment of 26 April 1979, Application No. 6538/74.

104 Joined Cases C-39/05 P and C-52/05 P Sweden and Maurizio Turco v. Council, para. 67.

${ }^{105}$ Case T-755/14 Herbert Smith Freehills LLP v. Commission, para. 63-72.

106 ECtHR, Österreichische Vereinigung v. Austria, para. 47.

${ }^{107}$ ECtHR, Társaság a Szabadságjogokért v. Hungary, para. 28.
} 
limited ${ }^{108}$; with respect to the issue of access to information under Article 10 ECHR, however, no relevant case law can be identified. ${ }^{109}$ The only EU law case where the issue of the application of Article 10 ECHR has been dealt substantively is the recent GC case of Association Justice \& Environment. ${ }^{110}$ Here, the GC quickly dismissed the potential applicability of ECtHR case law because the judgments were not precisely analogous to the case at hand: for example, none of the cited ECtHR cases dealt exactly with 'a request for access to documents in the context of a regime comparable to that of Regulation 1049/2001'. ${ }^{111}$ If the ECJ takes a similar line of reasoning in the future with respect to Article 10 ECHR and its relationship with Regulation 1049/2001, the desired convergence of the two European access to documents systems would appear to be rather unlikely.

Additionally, we argue that the jurisprudence of the CJEU with respect to the OPID is all the more confusing because it has been quite content to engage in substantive public interest balancing in other areas of the law. For example, the CJEU has held that the right to free movement of goods within the EU can be restricted by an express Treaty derogation or where its restriction is justified by 'overriding reasons in the public interest'. ${ }^{112}$ This concept of a public interest restriction is entirely judge-made, having its theoretical roots in the famous Cassis de Dijon decision, where the Court decided that such potential acceptable public interests include the effectiveness of fiscal supervision, fairness of commercial transactions, protection of the consumer and public health. ${ }^{113}$ Since Cassis de Dijon, this list of legitimate public interests has ballooned to include the protection of the environment, ${ }^{114}$ protection of animal welfare, ${ }^{115}$ protection of children, ${ }^{116}$ road safety ${ }^{117}$ and the prevention of fraud, ${ }^{118}$ to name just a few. Although more examples of the CJEU operating a public interest test could be provided here, ${ }^{119}$ the above is enough to show that it is not a court that is generally averse to engaging substantively with the legal public interest.

A final note concerns the arguments that have been run by applicants in CJEU access to documents cases. According to a number of pleadings to which we gained access, ${ }^{120}$ it appears as though a significant amount of applicants have essentially not even been attempting to pursue ECtHR-based public interest argumentation with respect to the OPID: this finding is rather surprising. We would have assumed that, at the very least, applicants would generally have attempted to argue on the basis of Article 10 ECHR with respect to the public interest

\footnotetext{
${ }^{108}$ See e.g. Case C-28/08 P Commission v Bavarian Lager, EU:C:2010:378, with respect to the relationship between access to documents and data protection issues.

${ }^{109}$ Advocate General Bobek has, however, interestingly appeared to advocate for Article 10 ECHR to be understood as a generally wide right to receive information and-pursuant to Article 52(3) of the Charter-for it to be applied in the EU, at least as far as judicial transparency goes. See his opinion in case Case C-213/15 P Commission v Breyer, EU:C:2016:994, para. 86-90.

110 Case T-727/15 Association Justice \& Environment z.s. v. Commission.

111 Ibid., para. 73.

112 See e.g., Case C-265/06 Commission v. Portugal, EU:C:2008:210, para. 38.

113 Case 120/78 Rewe-Zentral AG v. Bundesmonopolverwaltung für Branntwein, EU:C:1979:42.

114 Case 302/86 Commission v. Denmark, EU:C:1988:421.

115 Case C-219/07 Nationale Raad van Dierenkwkers en Liefhebbers and Andibel v. Belgium, EU:C:2008:353.

${ }^{116}$ Case C-244/06 Dynamic Medien Vertriebs GmbH v. Avides Media AG, EU:C:2008:85.

117 Case C-54/05 Commission v. Finland, EU:C:2007:168.

${ }^{118}$ Case C-161/09 Kakavetsos-Fragkopoulos v. Nomarchiaki Aftodiokisi Korinthias, EU:C:2011:110.

${ }^{119}$ For example, with respect to restrictions upon the free movement of workers, see Case C-415/93 Union royale belge des sociétés de football association and Others v. Bosman and Others, EU:C:1995:463; or with respect to the freedom of establishment, see Case C-55/94 Gebhard v. Consiglio dell'Ordine degli Avvocati e Procuratori di Milano, EU:C:1995:411.

${ }^{120}$ Applicant pleadings in a number of CJEU access to documents cases on file with the authors.
} 
when it came to producing their pleadings in access to documents cases. Although the CJEU seems unlikely to budge from its current OPID test, this finding reveals that there appears to remain a line of argumentation almost entirely unexplored by document applicants. As the CJEU has not yet dealt specifically with questions regarding the relationship between Article 10 ECHR and Regulation 1049/2011 pursuant to Article 52(3) of the Charter, it appears prudent on the part of future applicants to at least refer to ECtHR Article 10 jurisprudence as an alternative argument with respect to the OPID. ${ }^{121}$

\section{Conclusions}

The CJEU's interpretation of the right of access to documents differs greatly from the ECtHR's approach. Both of the courts have essentially the same right (right of access to documents) to interpret but the ultimate outcomes differ remarkably. The analysis of public interest argumentation by the ECtHR and CJEU above mostly explains the difference in their interpretative praxes: the CJEU does not evaluate the public interest involved in the information request in the same way as the ECtHR does.

For the sake of coherence of European fundamental rights with the ECHR system, and in accordance with the requirements imposed by Article 52(3) Charter, the CJEU should begin to take the ECtHR's approach to the right of access to documents seriously. In practice, this means that the CJEU should, at the very least, begin paying attention to the public interest that flows from the nature of the information being requested rather than placing an unpassable procedural roadblock in the way of applicants.

With respect to this point, it should be incumbent on the CJEU to, first, oblige the public institution concerned to comprehensively evaluate, with detailed statements to that effect, all public interests involved in the applicant's document request and, secondly, itself examine how the institution concerned has succeeded in balancing the competing interests against the public interest relating to the request. In this way, the CJEU can truly evaluate in each case whether there is an OPID with respect to the documents. The CJEU's current line of interpretation obliges the applicant to show specific circumstances as to whether there is an OPID. This obligation is clearly at odds with the principle of proportionality, since the applicant has littleand likely no-knowledge of the content of the requested document: yet such knowledge is necessary to pass the threshold of the CJEU's OPID test. In the ECHR system, the ECtHR has highlighted the obligations of the state to give 'relevant and sufficient' reasons why the refusal to disclose the documents concerned is justified in the case before them. ${ }^{122}$

The definition of public interest also affects how the right of access to documents is interpreted. The ECtHR has chosen to define the public interest broadly. The public interest relates to matters which 'affect the public to such an extent that it may legitimately take an interest in them, which attract its attention or which concern it to a significant degree, especially in that

\footnotetext{
${ }^{121}$ There are CJEU cases where it has followed the line of interpretation adopted by the ECtHR as required by Article 52(3) of the Charter. See e.g. Case C-180/17 X and $Y$ v. Staatssecretaris van Veiligheid en Justitie, EU:C:2018:775, para. 31; Case C-673/16 Relu Adrian Coman and Others v. Inspectoratul General pentru Imigrări and Ministerul Afacerilor Interne, EU:C:2018:385, para. 49-50. There are also cases where the CJEU has refused to follow the ECtHR's interpretation even if there was a corresponding right in question, see e.g. Case C-426/16 Liga van Moskeeën en Islamitische Organisaties Provincie Antwerpen, VZW and Others v. Vlaams Gewest, EU:C:2018:335, para. 40.

${ }^{122}$ ECtHR, Österreichische Vereinigung v. Austria, para. 47; ECtHR, Magyar Helsinki Bizottság v. Hungary, para. 200.
} 
they affect the well-being of citizens or the life of the community'. ${ }^{123}$ Further, the public interest is involved in matters which 'are capable of giving rise to considerable controversy, which concern an important social issue, or which involve a problem that the public would have an interest in being informed about'. ${ }^{124}$ More importantly, the public interest behind the information request affects the situation in several ways: if the ECtHR sees that the public interest involved in the information request is of 'a considerable public interest', it overrides other competing interests and is more likely to impose obligations upon the state to provide that information even if it would mean a substantial amount of work for the state authorities. ${ }^{125}$ Consequently the CJEU should also seek to develop a broad definition of the notion of the public interest in the context of access to documents - as it has already done in cases relating to freedom of movement - to enable the OPID to have a real function in the Regulation 1049/2001 transparency regime.

Overall, the CJEU has in the last decade moved generally towards more human rights-centered interpretations, placing a particular emphasis upon the importance of the effective protection of traditional human rights, such as the right to private life and the right to a fair trial. ${ }^{126} \mathrm{We}$ argue that the CJEU should now take one more step forward and similarly interpret the right of access to documents. As described above, the CJEU has all the means necessary to deal with the right of access to documents according to the ECtHR's standards: the promise of transparency at Treaty-level, a specific Charter provision on access rights, concretising secondary legislation, the CJEU's creative public interest argumentation in its, for example, free movement jurisprudence and the CJEU's dynamic rights-centered trend in human rights cases. In addition, the ECtHR is arguably moving ahead in its access to information jurisprudence $^{127}$ and there is a real risk that the two European access regimes will diverge for good if the CJEU does not soon change its course. Given the now essentially accepted fundamental nature of government openness to the future of a healthy democracy, the EU should not be seen to fall behind in its pursuit.

\footnotetext{
${ }^{123}$ ECtHR, Magyar Helsinki Bizottság v. Hungary, para. 162.

124 Ibid.

${ }^{125}$ ECtHR, Österreichische Vereinigung v. Austria, para. 46.

${ }^{126}$ See e.g. Joined Cases C-293/12 and C-594/12 Digital Rights Ireland, EU:C:2014:238; Joined Cases C-203/15 and C-698/15 Tele2 Sverige and Watson and Others, EU:C:2016:970; Case C-300/11 ZZ, EU:C:2013:363; Joined Cases C-584/10 P, C-593/10 P and C-595/10 P Commission and Others v. Kadi, EU:C:2013:518.

127 The ECtHR is currently deciding whether Article 10 ECHR also includes public access to court documents, see pending case ECtHR, Studio Monitor and Zuriashvili v. Georgia, Application No. 44920/09, communicated on 8 September 2016. Further, the ECtHR has recently held that information regarding pending criminal proceedings is also protected under Article 10 ECHR (ECtHR, Brisc v. Romania, Judgment on 11 December 2018, Application No. 26238/10).
} 